\title{
AN INSIGHT INTO THE IMPACT OF ARABLE FARMING ON IRISH BIODIVERSITY: A SCARCITY OF STUDIES HINDERS A RIGOROUS ASSESSMENT
}

\author{
Martin O'Brien, Charles Spillane, Conor Meade and Ewen Mullins
}

\begin{abstract}
To help understand and counteract future agronomic challenges to farmland biodiversity, it is essential to know how present farming practices have affected biodiversity on Irish farms. We present an overview of existing research data and conclusions, describing the impact of crop cultivation on biodiversity on Irish arable farms. An extensive literature review clearly indicates that peer-reviewed publications on research conducted in Ireland on this topic are quite scarce: just 21 papers investigating the effect of conventional crop cultivation on Irish biodiversity have been published within the past 30 years. Principally, these studies have concluded that conventional crop cultivation has had an adverse impact on biodiversity on Irish farms, with 15 of the 21 studies demonstrating negative trends for the taxa investigated. Compared to other EU states, the relative dearth of baseline data and absence of monitoring programmes designed to assess the specific impacts of crop cultivation on Irish biodiversity highlight the need to develop long-term research studies. With many new challenges facing Irish agriculture, a research programme must be initiated to measure current levels of biodiversity on arable land and to assess the main farming 'pressures' causing significant biodiversity loss or gains in these systems.
\end{abstract}

Ewen Mullins (corresponding author; email: ewen.mullins@ teagasc.ie) and Martin O'Brien, Plant Biotechnology Unit, Teagasc Crops Research Centre, Oak Park, Carlow; Conor V. Meade, Molecular Ecology Laboratory, institute of Bioengineering and Agroecology, Department of Biology, National University of Ireland, Maynooth; Charlie Spillane, Genetics \& Biotechnology Lab. Department of Biochemistry \& Biosciences Institute, Lee Maltings 2.10, University College Cork.

Received 12

September 2007. Accepted 4 March 2008. Published 27 August 2008

\section{INTRODUCTION}

Although agriculture led to the development of human civilisation and is required for the continuity of human society, it has also been identified as one of the principal contributors to the loss of biodiversity worldwide, largely because of the vast terrestrial areas of the planet devoted to farming (McLaughlin and Mineau 1995; Goklany 1998). The high degree of physical manipulation (ploughing, irrigation, etc.) and high inputs of pesticides and fertilisers inherent in many farming models also impact on biodiversity (McLaughlin and Mineau 1995). While the 'green revolution' of the 20 th century significantly increased their extent and intensity, these impacts have nonetheless been a feature of agriculture since the very beginning (Diamond 2005). The timeline of agricultural development in Ireland has seen the loss of primary broadleaf-forest cover on the island, reductions of floral diversity in natural grasslands and losses of animals such as wolves and eagles, and the drainage of bogs and marshes has led to the loss of bird species such as the bittern (Botaurus stellaris) (Mitchell and Ryan 1997; Feehan 2003). Conversely, successive waves of agricultural development have been responsible for many species introductions to Ireland, whether as introduced domesticated or edible species, such as rabbit (Oryctolagus cuniculus), or as weedy species, such as wild oats (Avena fatua) and the darnel (Lolium temulentum) (Reynolds 2002; Stokes et al. 2004).

Tillage and land-use systems in Ireland continue to change (e.g. the modern declines in flax and sugar-beet cultivation or increases in maize and oilseed-rape cultivation), and new floral and faunal elements appear from overseas all the time, so current arable farmland biodiversity should be properly interpreted as part of a longer-term flux where change is the norm. Therefore, baseline data regarding biodiversity change will have to be anchored towards specific tillage systems and will have to define the timescales of biodiversity change that are of relevance. Equally, these measurements require analysis of both numbers of species and also the density and diversity of individuals and populations within species.

Perhaps the most striking knowledge gap evident from the literature is that the direct contribution of tillage-based agriculture to species decline, as opposed to decline caused by other land uses (e.g. grassland, etc.), has not been quantified for Ireland. Arable land receives heavier applications of pesticides (Meade and Mullins 2005) and is cultivated more frequently (annually) than 
grassland (approximately 53\% of pastures in Ireland have not been cultivated for reseeding in more than ten years; O'Brien et al. 2008), so there is greater pressure on the various species present. While environmental pressures faced here may differ from other European countries (see below), many EU studies suggest that major recent declines in biodiversity are associated with agricultural change, particularly since the 1950 s, and we might expect a similar trend to be evident here (Donald et al. 2001; Robinson and Sutherland 2002). These apparent changes have been a major driver for legally binding conservation policy at an EU level.

Ireland (primarily referring to the Republic of Ireland from this point on, unless stated otherwise) is unique in Europe in that agriculture is overwhelmingly grassland oriented, with a predominance of small fields: just $10 \%$ of farmland is arable (some 0.42 million ha), mostly comprised of cereals ( 0.31 million ha), with the remaining $90 \%$ (3.8 million ha) devoted to pasture, meadow and silage (European Environment Agency 2005; Department of Agriculture and Food 2006a). Within the arable farmland it is evident that recent changes have significantly impacted on habitat quality; for example, arterial and field drainage, land reclamation (including the removal of small-scale farmland habitats such as trees, hedges, drystone walls, remnant woodlands and scrub) and the increasing use of fertilisers and pesticides (insecticides, fungicides and herbicides) (Feehan 2003).

External inputs, such as pesticides and fertilisers, are a major feature of crop production in Ireland. Total pesticide inputs for arable crops in 2004 (based on active substances) amounted to 1,520 tonnes, including 663 tonnes of herbicide, 619 tonnes of fungicide, 29 tonnes of insecticide and 209 tonnes of other plant-protection products (e.g. growth regulators, molluscicides, etc.) (Department of Agriculture and Food 2007). Overall, there has been an $18.4 \%$ increase in pesticide usage (based on sales) since 1990 (Organisation for Economic Cooperation and Development (OECD) 2004), although the average amount of pesticide used in 2001 was $0.5 \mathrm{~kg}$ active ingredient per ha of Irish agricultural land, which was the lowest in the EU15. However, the low level of pesticide usage in Ireland would seem to reflect the relatively small proportion of land dedicated to arable farming compared to other EU countries and the lower quantity of pesticide usage on grassland farms (Department of Agriculture and Food 2006b).

As farming has intensified, the use of artificial (inorganic) $\mathrm{N}$ fertiliser has also increased, both to increase yields and to improve nutritional status (Smil 2002). However, only a fraction of the $\mathrm{N}$ applied is used in plant growth or retained in food products; the excess leads to biodiversity loss and reduced water quality (Hassan et al. 2005). The quantities used on Irish farms increased from 48,000 tonnes in $1966-7$ to 275,000 tonnes in 1980 (Murphy 1982) and continued to increase from 370,000 tonnes in 1990 up to 444,000 tonnes in 1998 (OECD 2004). As the cost of fertiliser $N$ has increased in recent years, and the EU Water Framework Directive has come into force in Ireland, there has been some reduction in usage. In 2003388,000 tonnes of $\mathrm{N}$ and 44,000 tonnes of $\mathrm{P}$ were used on Irish farms, with land for arable crops receiving a higher unit application of each nutrient (Coulter et al. 2005). Nitrogen usage for cereals increased by approximately $11 \%$ from 1995 to 2003 , but $\mathrm{P}$ use remained constant. In the same period the usage of $\mathrm{N}$ and $\mathrm{P}$ for root crops (e.g. turnip, potato, sugar beet and fodder beet) decreased markedly by $14 \%$ and $24 \%$, respectively (Coulter et al. 2005). As of 2001, Ireland applies $130 \mathrm{~kg}$ of NPK fertiliser per ha of farmed land compared to the OECD average of $123 \mathrm{~kg} \mathrm{ha}^{-1}$. This rate is the sixth highest of the EU-15, with the Netherlands $\left(210 \mathrm{~kg} \mathrm{ha}^{-1}\right)$ being the highest and Greece (49kg ha ${ }^{-1}$ ) being the lowest (OECD 2004).

This paper aims to provide an insight into existing research data and conclusions from peerreviewed publications regarding the impact of crop cultivation on biodiversity on Irish tillage farms. Although there is an abundance of literature on this topic collated from other regions in Europe and elsewhere (e.g. McLaughlin and Mineau 1995 (Canada); Robinson and Sutherland 2002 (Great Britain)), such a record does not exist for Ireland. In addition to the varied climate and different agronomic systems in Ireland, we cannot rely too heavily on ex situ studies because, in comparison with Great Britain and continental Europe, the terrestrial fauna and flora of Ireland is relatively impoverished, reflecting Ireland's isolation by sea since the last glaciation (Costello 1993; Mitchell and Ryan 1997). Given the relative lack of Irish research on this issue in general, the purpose of this review is to ascertain through published, peer-reviewed scientific literature exactly what is known about the positive and negative impacts of conventional crop cultivation on inter- and intra-species biodiversity on farms on the island of Ireland. The literature review is primarily limited to comparative/experimental studies that target specific arable cropping systems, rather than baseline data available in databases or in local natural-history or biogeographical journals. 


\section{IMPACT OF CONVENTIONAL CROP CULTIVATION ON BIODIVERSITY ON IRISH TILLAGE FARMS}

Reduced levels of biodiversity are associated with increased intensity of management and reduced environmental heterogeneity (Erwin 1996). A number of species and species assemblages in Ireland are dependent upon the continuation of specific agricultural practices for their survival (see below). However, changes in and intensification of modern agricultural practice, such as the switch from spring to winter crops, the loss of marginal hedgerows and the decline in the area under cultivation, have over the past three decades caused a dramatic decrease in many species that are dependent on traditional arable practices, such as bristle oat (Avena strigosa) and darnel (Lolium temulentum) (Curtis et al. 1988; The Heritage Council 1999; Taylor and O'Halloran 2002). Similarly, the loss of overwintering stubble and the abandonment of small-scale rotational cropping have had an adverse impact on biodiversity (The Heritage Council 1999; Taylor and O'Halloran 2002; McMahon et al. 2003). Marginal hedgerows and wet flush areas are a characteristic feature of the Irish farming landscape and form important wildlife habitats for animals and plants (Mitchell and Ryan 1997; Feehan 2003). Webb (1988) estimated that approximately $16 \%$ of all hedges have disappeared since 1938, and the total area drained under various Acts and Schemes is 2.02 million ha, or almost $38 \%$ of the total land area farmed on the island of Ireland. Although the focus in this current paper is on arable systems, it is possible that the impacts of such changes are also likely to be as great on the biodiversity of pastoral systems (Green and Stowe 1993; Hutton and Giller 2003; Purvis et al. 2005).

Research on the effects of agricultural practices on Irish levels of biodiversity was collated from a literature search, using ISI Web of Science (19452006), BIOSIS Previews (1980-2006) and CAB Direct (1973-2006). There have also been a number of relevant $\mathrm{MSc}$ and $\mathrm{PhD}$ theses in Ireland completed on this topic in the last decade (e.g. Fadl 1996; Davis 2004; Bracken 2004; McMahon 2005; Golden 2005; Brennan 2005). However, only peer-reviewed articles stemming from those theses have been included here, with the caveat that some of the studies are of a higher scientific standard and are published in higherimpact journals than others.

Considering the importance of agriculture to the Irish economy and the increasing national interest in biodiversity, it is of some concern that only 21 published, peer-reviewed scientific articles have investigated the impact of crop cultivation on farmland biodiversity in Ireland over the last three decades (twenty studies in the Republic of Ireland and one study in Northern Ireland; Table 1). Three of these studies were published in the 1980s, and three in the 1990s. However, since 2000, the rate of publication has increased, with fifteen scientific papers published in the last seven years. The majority of this research has focused on improving soil-management practices (i.e. crop rotation/ effects of cultivation and intercropping, 9 of 21 studies), the benefits of maintaining hedgerows/ forests crossing or bordering tillage fields $(3 / 21)$ and the adverse effects of intensification (3/21) (Fig. 1). Other research areas studied included pesticide usage, set-aside and stubble, organic farming and the Rural Environment Protection Scheme (REPS). Fifteen studies assessed the effects of cropping using biodiversity 'indicator' species such as various invertebrate groups (of agronomic importance), with one of these studies also examining vascular plants; five others focused on birds (that were either very rare or very common); and one focused on mammals (bats). The most-studied invertebrates in these papers were earthworms, carabid beetles and collembola (springtails). Bats and bumblebees were the only mammals (Russ and Montgomery 2002) and airborne insects (Santorum and Breen 2005) studied as biodiversity indicator species, respectively. The choice of species to be used as indicators of biodiversity change remains a somewhat contested question, in addition to the ecological questions that such indicator species can answer. As in many countries and ecosystems, biodiversity-change studies in Ireland have mainly taken a community-ecology approach, often on a few groups of organisms, including invertebrates, songbirds and small mammals (Pereira and Cooper 2006; Thompson 2006). Based on the conclusions of the literature reviewed for this review, the impact of arable farming practices on these various organisms has been summarised as follows:

\section{SOIL MANAGEMENT PRACTICES}

Earthworms are one of the most important groups of beneficial soil invertebrates in cropping systems in north-western Europe, contributing to soil fertility and productivity (Lee 1985). Carabid beetles in agricultural crop systems have a beneficial role as polyphagous predators of pest species (Thiele 1977; Luff 1987), and springtails can be microphages, feeding on soil microflora, and/or detritivores, scavenging on dead organic matter and plant litter (Bardgett et al. 1993). Under Irish conditions, conventional soil cultivation (i.e. mechanical ploughing, tilling, etc.) has been found to have an adverse effect on the species diversity of soil organisms, such as earthworms (Schmidt and Curry 2001; Schmidt et al. 2001; Curry et al. 2002), carabid beetles (Fadl et al. 1996; Purvis et al. 
Table 1-Pre-existing peer-reviewed research data describing the impact of conventional crop cultivation on Irish levels of biodiversity (1980-2006).

\begin{tabular}{|c|c|c|c|c|c|c|c|}
\hline $\begin{array}{l}\text { Investigated } \\
\text { species/group }\end{array}$ & Crop(s) & Study & $\begin{array}{l}\text { Statistical } \\
\text { analysis }\end{array}$ & $\begin{array}{c}\text { Study } \\
\text { duration }\end{array}$ & Results & $\begin{array}{l}\text { Impact on } \\
\text { biodiversity' }\end{array}$ & Reference \\
\hline $\begin{array}{l}\text { Arthropod } \\
\text { fauna }\end{array}$ & $\begin{array}{l}\text { Barley \& } \\
\text { grass-white } \\
\text { clover }\end{array}$ & $\begin{array}{l}\text { Successional changes in } \\
\text { arthropod fauna of a } \\
\text { newly established ley } \\
\text { pasture that was } \\
\text { previously cultivated } \\
\text { arable land }\end{array}$ & Yes & $1975-7$ & $\begin{array}{l}\text { Soil and foliage } \\
\text { communities increased } \\
\text { in species richness after } \\
\text { grassland was established } \\
\text { on arable land. }\end{array}$ & $\downarrow$ & $\begin{array}{l}\text { Purvis and } \\
\text { Curry (1980) }\end{array}$ \\
\hline $\begin{array}{l}\text { Carabid } \\
\text { beetles }\end{array}$ & Sugar beet & $\begin{array}{l}\text { Comparison of manure } \\
\text { application at the time of } \\
\text { sowing and unrestricted } \\
\text { weed growth with } \\
\text { controls }\end{array}$ & Yes & 1979 & $\begin{array}{l}\text { Manure application } \\
\text { immediately encouraged } \\
\text { early-season carabid } \\
\text { communities. }\end{array}$ & $\downarrow$ & $\begin{array}{l}\text { Purvis and } \\
\text { Curry (1984) }\end{array}$ \\
\hline $\begin{array}{l}\text { Arthropod } \\
\text { fauna }\end{array}$ & Winter wheat & $\begin{array}{l}\text { Effects of various } \\
\text { methods of methiocarb } \\
\text { application on non- } \\
\text { target invertebrates }\end{array}$ & Yes & $1980-1$ & $\begin{array}{l}\text { Single applications of } \\
\text { methiocarb granules did } \\
\text { not adversely affect the } \\
\text { predatory and } \\
\text { decomposer fauna. }\end{array}$ & $\leftrightarrow$ & $\begin{array}{l}\text { Kelly and } \\
\text { Curry (1985) }\end{array}$ \\
\hline $\begin{array}{l}\text { Staphylinid } \\
\text { beetles }\end{array}$ & $\begin{array}{l}\text { Spring cereals, } \\
\text { winter cereals, } \\
\text { hay meadow, } \\
\text { lightly grazed } \\
\text { pastures \& } \\
\text { silage fields }\end{array}$ & $\begin{array}{l}\text { Effects of different } \\
\text { cereal- and grass- } \\
\text { management regimes } \\
\text { on summer staphylinid } \\
\text { assemblages }\end{array}$ & Yes & 1986 & $\begin{array}{l}\text { Large differences in } \\
\text { staphylinid assemblages } \\
\text { occurred between } \\
\text { undisturbed meadows } \\
\text { and pastures and } \\
\text { disturbed silage fields } \\
\text { and cereals. }\end{array}$ & $\downarrow$ & $\begin{array}{l}\text { Good and } \\
\text { Giller (1991) }\end{array}$ \\
\hline $\begin{array}{l}\text { Carabid } \\
\text { beetles }\end{array}$ & Winter wheat & $\begin{array}{l}\text { Effect of repeated annual } \\
\text { application of } \\
\text { methiocarb-based slug } \\
\text { pellets on carabid beetle } \\
\text { activity }\end{array}$ & Yes & 1987-91 & $\begin{array}{l}\text { Even though } \\
\text { methiocarb application } \\
\text { can severely depress } \\
\text { winter-active carabid } \\
\text { populations, the } \\
\text { long-term } \\
\text { environmental harm of } \\
\text { this non-target effect } \\
\text { appears to be relatively } \\
\text { slight. }\end{array}$ & $\leftrightarrow$ & $\begin{array}{l}\text { Purvis and } \\
\text { Bannon } \\
(1992)\end{array}$ \\
\hline $\begin{array}{l}\text { Pterostichus } \\
\text { melanarius } \\
\text { (beetle) }\end{array}$ & Mixed tillage & $\begin{array}{l}\text { Comparison of four } \\
\text { different timed } \\
\text { cultivation histories }\end{array}$ & Yes & $1992-4$ & $\begin{array}{l}\text { Spring soil cultivation } \\
\text { reduces larval/pupal } \\
\text { survival, but rapid } \\
\text { inter-field dispersal by } \\
\text { adults masks the effects } \\
\text { of soil cultivation on } \\
\text { individual fields. }\end{array}$ & $\leftrightarrow$ & $\begin{array}{l}\text { Fadl et al. } \\
(1996)\end{array}$ \\
\hline $\begin{array}{l}\text { Carabid } \\
\text { beetles }\end{array}$ & $\begin{array}{l}\text { Mixed tillage } \\
\& \text { grassland }\end{array}$ & $\begin{array}{l}\text { Effect of different } \\
\text { timings of annual soil } \\
\text { cultivation on numbers } \\
\text { and types of beetles }\end{array}$ & Yes & $1992-4$ & $\begin{array}{l}\text { In a mixed farming } \\
\text { system, a greater degree } \\
\text { of species coexistence } \\
\text { and biodiversity is } \\
\text { possible compared to } \\
\text { monoculture farming } \\
\text { with synchronised soil } \\
\text { cultivation. }\end{array}$ & $\downarrow$ & $\begin{array}{l}\text { Purvis et al. } \\
(2001)\end{array}$ \\
\hline
\end{tabular}


Table 1 (Continued)

\begin{tabular}{|c|c|c|c|c|c|c|c|}
\hline $\begin{array}{l}\text { Investigated } \\
\text { species/group }\end{array}$ & $\operatorname{Crop}(s)$ & Study & $\begin{array}{l}\text { Statistical } \\
\text { analysis }\end{array}$ & $\begin{array}{c}\text { Study } \\
\text { duration }\end{array}$ & Results & $\begin{array}{l}\text { Impact on } \\
\text { biodiversity }\end{array}$ & Reference \\
\hline Earthworms & $\begin{array}{l}\text { Winter wheat } \\
\text { \& winter } \\
\text { wheat-white } \\
\text { clover }\end{array}$ & $\begin{array}{l}\text { Effect of winter wheat-- } \\
\text { white clover } \\
\text { intercropping system } \\
\text { (low input, direct drill) } \\
\text { compared to } \\
\text { conventional } \\
\text { monocropping }\end{array}$ & No & $1994-6$ & $\begin{array}{l}\text { The combination of } \\
\text { absence of tillage and } \\
\text { continuous supply of } \\
\text { plant residues of high } \\
\text { nutritional value in the } \\
\text { wheat-clover } \\
\text { intercropping system } \\
\text { was beneficial to } \\
\text { earthworms. }\end{array}$ & $\downarrow$ & $\begin{array}{l}\text { Schmidt and } \\
\text { Curry (2001) }\end{array}$ \\
\hline Earthworms & $\begin{array}{l}\text { Winter wheat } \\
\& \text { winter } \\
\text { wheat-white } \\
\text { clover mix }\end{array}$ & $\begin{array}{l}\text { Effect of low-input, } \\
\text { direct-drill intercropping } \\
\text { system compared to } \\
\text { conventional } \\
\text { monocropping }\end{array}$ & Yes & $1993-7$ & $\begin{array}{l}\text { The results show } \\
\text { unequivocally that the } \\
\text { wheat-clover cropping } \\
\text { system supported larger } \\
\text { earthworm cornmu- } \\
\text { nities than conventional } \\
\text { wheat monocropping. }\end{array}$ & $\downarrow$ & $\begin{array}{l}\text { Schmidt } \\
\text { et al. }(2001)\end{array}$ \\
\hline Earthworms & $\begin{array}{l}\text { Wheat, potato } \\
\text { \& spring } \\
\text { barley }\end{array}$ & $\begin{array}{l}\text { Impact of intensive } \\
\text { cultivation }\end{array}$ & No & $\begin{array}{l}1994- \\
2000\end{array}$ & $\begin{array}{l}\text { Earthworm populations } \\
\text { can be virtually } \\
\text { eliminated within a } \\
\text { single season by drastic } \\
\text { forms of soil cultivation. }\end{array}$ & $\downarrow$ & $\begin{array}{l}\text { Curry et al. } \\
(2002)\end{array}$ \\
\hline $\begin{array}{l}\text { Carabid } \\
\text { beetles }\end{array}$ & Potato & $\begin{array}{l}\text { Compare carabid beetle } \\
\text { communities in organic } \\
\text { and conventional potato } \\
\text { crops }\end{array}$ & No & 1999 & $\begin{array}{l}\text { Greater abundance and } \\
\text { diversity of carabid } \\
\text { beetles were found in } \\
\text { the organic plots. }\end{array}$ & $\downarrow$ & $\begin{array}{l}\text { O'Sullivan } \\
\text { and } \\
\text { Gormally } \\
(2002)\end{array}$ \\
\hline $\begin{array}{l}\text { Carabid } \\
\text { beetles }\end{array}$ & $\begin{array}{l}\text { Mixed tillage } \\
\& \\
\text { uncultivated } \\
\text { grass leys }\end{array}$ & $\begin{array}{l}\text { Compare crop-rotation } \\
\text { and soil-cultivation } \\
\text { effects on beetles }\end{array}$ & Yes & $1993-5$ & $\begin{array}{l}\text { Autumn-breeding } \\
\text { carabid species were less } \\
\text { common in early } \\
\text { summer when soil } \\
\text { cultivation was carried } \\
\text { out in late spring } \\
\text { compared with } \\
\text { uncultivated or } \\
\text { autumn-sown fields. }\end{array}$ & $\downarrow$ & $\begin{array}{l}\text { Purvis and } \\
\text { Fadl (2002) }\end{array}$ \\
\hline Bats & $\begin{array}{l}28 \text { habitat } \\
\text { types }\end{array}$ & $\begin{array}{l}\text { Species richness in the } \\
\text { Northern Ireland } \\
\text { countryside }\end{array}$ & No & $1996-8$ & $\begin{array}{l}\text { Reduction in areas and } \\
\text { quality of habitats such } \\
\text { as field boundaries } \\
\text { may impact on bat } \\
\text { populations. }\end{array}$ & $\downarrow$ & $\begin{array}{l}\text { Russ and } \\
\text { Montgomery } \\
(2002)^{2}\end{array}$ \\
\hline $\begin{array}{l}\text { Corn } \\
\text { bunting }\end{array}$ & $\begin{array}{l}\text { Cereals } 8 \\
\text { other tillage } \\
\text { crops }\end{array}$ & $\begin{array}{l}\text { Survey of potential corn } \\
\text { bunting habitats in } \\
\text { counties Donegal, Mayo } \\
\text { and Galway }\end{array}$ & No & 1998 & $\begin{array}{l}\text { No corn buntings were } \\
\text { seen or heard at any of } \\
\text { these sites. }\end{array}$ & $\downarrow$ & $\begin{array}{l}\text { Taylor and } \\
\text { O'Halloran } \\
(2002)\end{array}$ \\
\hline Birds & $\begin{array}{l}\text { Stubble, } \\
\text { set-aside, } \\
\text { grassland \& } \\
\text { winter wheat }\end{array}$ & $\begin{array}{l}\text { Species richness in } \\
\text { farmland }\end{array}$ & Yes & $2001-2$ & $\begin{array}{l}\text { Stubble supports the } \\
\text { greatest species richness } \\
\text { and diversity, with the } \\
\text { lowest being recorded } \\
\text { on improved grassland. }\end{array}$ & $\uparrow$ & $\begin{array}{l}\text { McMahon } \\
\text { et al. (2003) }\end{array}$ \\
\hline
\end{tabular}


Table 1 (Continued)

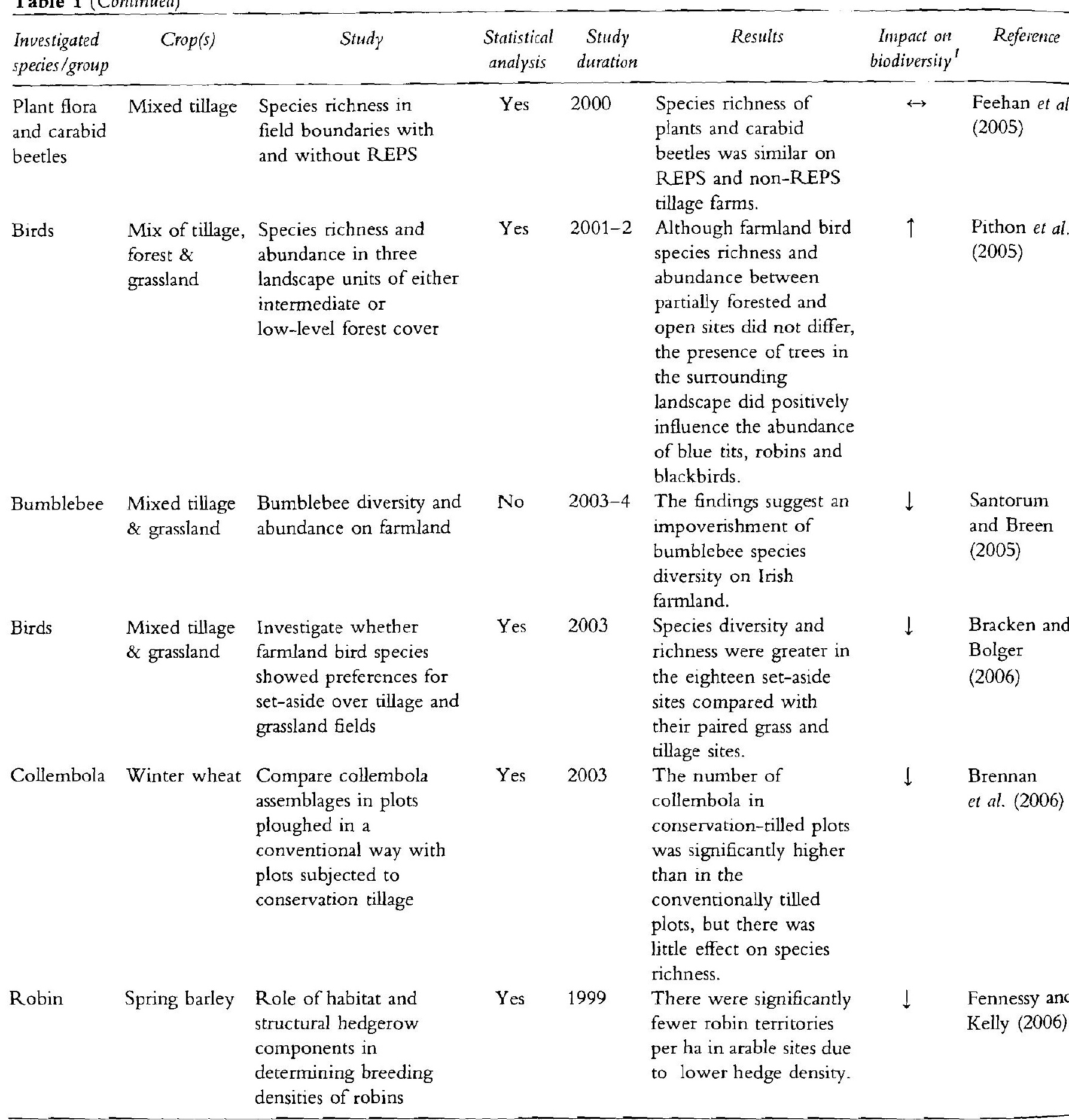

\footnotetext{
${ }^{1}$ Impact of conventional crop cultivation on biodiversity either (i) prior to the land being used for other purposes (e.g. meadow, pastures), (ii) compared to altemative environment-friendly farning practices, such as intercropping, minimum tillage, timing of cultivation, organic farming, set-aside, winter stubble and farming under REPS, or (iii) resulting from the general intensification of faming practices.

${ }^{2}$ Northern Ireland.
} 


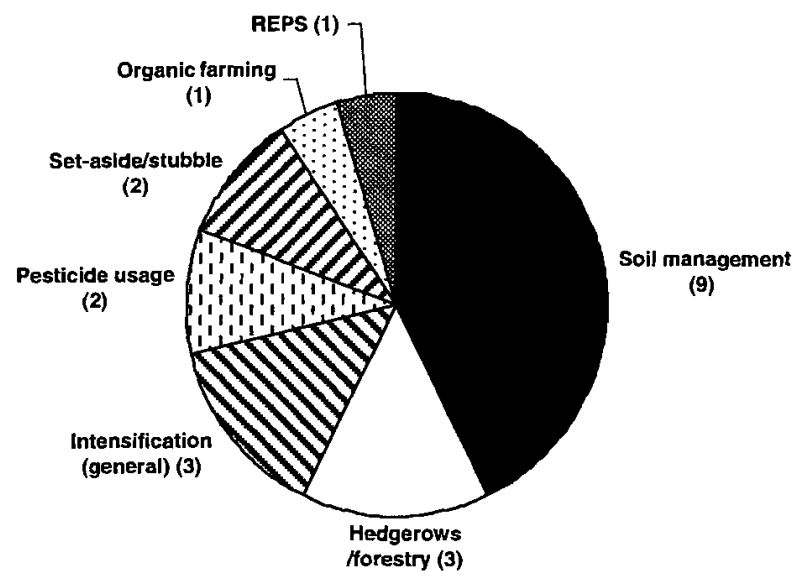

Fig. 1-Arable farming operations and practices that have been shown as having either a positive or negative impact on Irish levels of farmland biodiversity ( $n=21$ published studies). Data collated from peer-reviewed publications using ISI Web of Science (1945-2006), BIOSIS Previews (1980-2006) and CAB Direct (1973-2006).

2001; Purvis and Fadl 2002), collembola (Brennan et al. 2006) and other arthropods (Purvis and Curry 1980). In contrast, minimum tillage (Brennan et al. 2006), minimum tillage with intercropping (Schmidt et al. 2001; Schmidt and Curry 2001), reversion of land from tillage to grassland (Purvis and Curry 1980) and timing of cultivation (Fadl et al. 1996; Purvis et al. 2001; Purvis and Fadl 2002) have all been shown to be less detrimental to populations of these organisms. Farmyard-manure application to soil at the time of sowing has also been shown to significantly encourage early-breeding carabid communities (Purvis and Curry 1984). The use of manure replenishes $N$ and other elements in the soil and builds up soil organic-matter content. This generally supports a greater abundance of invertebrates that rely on non-degraded plant matter as a food source (Hole et al. 2005).

\section{HEDGEROWS AND FORESTRY}

$\mathrm{U}_{\mathrm{p}}$ to $1.5 \%$ of the total land area of Ireland is accounted for by hedgerows (Webb 1988). Hedgerows accommodate a greater total of breeding birds than any other farmland feature by providing movement corridors; protection from predators; and nesting, feeding and roosting sites (O'Connor and Shrubb 1986; Lack 1992). The presence of hedgerows and forests in and around tillage farms has had a positive effect on populations of bats and certain birds, such as the blue tit (Parus caeruleus), robin (Erithacus rubecula) and blackbird (Turdus merula) (Russ and Montgomery 2002; Pithon et al. 2005; Fennessy and Kelly 2006). The loss of hedgerows represents a direct loss of foraging habitat for several bat species (Russ and Montgomery 2002) and of feeding, nesting and roosting sites for bird species such as the robin (Fennessy and Kelly 2006). Fennessy and Kelly (2006) found that arable sites had significantly fewer robin territories per ha than either improved or semi-improved grassland sites. This may be explained by the fact that hedge density was significantly lower in arable land than in the other two farmland groupings.

\section{INTENSIFICATION OF FARMING}

Agricultural intensification can be defined as the production of more agricultural goods with the same amount of resources, such as land and water. The intensification of Irish agriculture has been implicated in the impoverishment of bumblebee species diversity (Santorum and Breen 2005) and the decline and extirpation of the corn bunting (Miliaria calandra) from much of its range (Taylor and O'Halloran 2002). Bumblebees are an important part of the Irish fauna, particularly as pollinators of both wild plants and agricultural crops. Bumblebees that would be naturally rare are now very scarce or absent from the typical agricultural landscapes surveyed (Santorum and Breen 2005). With regards to the corn bunting, the most important factors in its demise in western European countries, including Ireland, are thought to be the decline in mixed farming and the loss of temporary grasslands, hay meadows and undersown cereals, especially spring cereals and overwintering cereal stubbles. These crops provided the preferred breeding and overwintering habitats, and the use of pesticides is proposed to have possibly reduced the availability of invertebrate and seed food supplies (Taylor and O'Halloran 2002).

Predatory staphylinid beetles comprise one of the groups of polyphagous natural enemies of pest insects in cereals and agricultural grasslands (Good and Giller 1988). Good and Giller (1991) examined the effects of different cereal-and grass-management regimes on summer staphylinid assemblages in hay meadows, lightly grazed pastures, silage fields, spring 
cereals and winter cereals with routine pesticide applications. Large differences in staphylinid assemblages occurred between undisturbed meadows and pastures (without cultivation, cutting, heavy grazing or fertiliser use) and disturbed silage fields and cereals. Application of dimethoate insecticide resulted in a reduction in species richness in cereals, but no effect was evident from the use of the fungicide propiconazole. Overall, rapid recolonisation in heterogeneous landscapes, as in this study, lessened the perceived impact of disturbance factors (Good and Giller 1991).

\section{PESTICIDE USAGE}

Two studies have analysed the impact of pesticide usage on Irish biodiversity (Kelly and Curry 1985; Purvis and Bannon 1992). A single application of methiocarb-based slug pellets was found not to adversely affect predatory and decomposer fauna (Kelly and Curry 1985), but repeated annual broadcast and drilled applications severely depressed the populations of winter-active carabid populations to less than $5 \%$ and $10-15 \%$, respectively, compared with untreated plots (Purvis and Bannon 1992). However, the long-term environmental harm of applying methiocarb-based slug pellets on non-target organisms appeared to be relatively slight in those authors' opinion (Purvis and Bannon 1992). Although the effects of herbicides have only been tentatively studied on arable farms (Feehan et al. 2005), it is believed that their use over the past half-century has halved the number of wild plants and animal species associated with farmland and has greatly reduced the overall population size of most species (Feehan 2003).

\section{WINTER STUBBLE AND SET-ASIDE}

Winter stubble and spring-sown cereals have been relatively common features of the Irish landscape in recent centuries, up to the spread of winter sowing in the 1980s (Feehan 2003). Winter stubble comprises an important food source for many species of farmland birds over the winter months, and spring-sown cereal crops provide favourable nesting conditions for ground-nesting birds, such as skylarks (Alauda arvensis), which have suffered a decline of $25-50 \%$ in breeding populations over the last 25 years (Newton et al. 1999; Taylor and O'Halloran 2002; McMahon 2005). Set-aside was initially introduced in 1992 to reduce overproduction and agricultural surpluses in the EU (Buckingham et al. 1999). 'Green' set-aside has since emerged within the context of multifunctional agriculture in the EU to also become part of some agri-environment schemes (Sotherton 1998). Rotational set-aside helps to maintain more land under winter stubble, as farmers previously would plough their fields soon after harvest in readiness for sowing the following year's crops. On the other hand, non-rotational set-aside is land that is left fallow for several years and that may be sown either with grass or with naturally regenerated vegetation. McMahon et al. (2003) showed that arable farms that retained stubble throughout the winter supported the greatest diversity of birds. Bracken and Bolger (2006) found birds exhibited a significant preference for set-aside over non-setaside fields (i.e. grass and tillage sites), with non-rotational set-aside having the greatest abundances of species, such as skylark and meadow pipit (Anthus pratensis).

\section{RURAL ENVIRONMENT PROTECTION SCHEME}

Following the implementation of Council Regulation (EEC) 2078/92, REPS was introduced to Ireland in 1994 (the Northern Ireland equivalent is the Environmental Sensitive Area scheme and/or Countryside Management Scheme). REPS is intended to monetarily reward farmers for carrying out their farming activities in an environmentally friendly manner and to bring about environmental improvement on existing farms. The fifth Common Agriculture Policy (CAP) reform established common conditions for direct payments to farmers under the various income-support schemes and provided support for the agri-environment. Since its launch in 1994, over 45,000 Irish farmers have joined REPS, with approximately $39 \%$ (or 1.7 million ha) of the utilisable agricultural area of Ireland being farmed under REPS guidelines.

One of the original stated objectives of REPS was to protect wildlife habitats and endangered species of flora and fauna' (Teagasc 2007), but throughout the scheme's specifications the main emphases have been extensification and waterpollution reduction (Feehan et al. 2005). However, investigating the plant flora and carabid beetle species richness in field boundaries on REPS and non-REPS tillage farms, Feehan et al. (2005) found species richness was actually similar on both. The authors concluded that farms that had participated in the scheme for at least four years, so far, showed little beneficial impact on the diversity of flora and surveyed fauna groups. As the study relied on data from short- and medium-term monitoring, the authors acknowledged that a longer-term study is required.

\section{ORGANIC FARMING}

At the end of 2006 there were approximately 72 organic arable farmers in Ireland, farming 620 ha, which represented approximately $0.1 \%$ of the agricultural land area (Shortle et al. 2007). 
Organic agriculture is based on a broad set of principles, including the way people tend soils, water, plants and animals in order to produce, prepare and distribute food and other goods. These principles are set out in the International Federation of Organic Agriculture Movements (IFOAM) norms for organic production and processing (IFOAM 2006). Organic farming systems tend to rely on crop rotation, crop residues, animal manures and mechanical cultivation to maintain soil productivity, to supply plant nutrients and to control weeds, insects and other pests. While there are many environmental claims that organic agriculture is more beneficial to biodiversity and the environment (Mäder et al. 2002; Holzschuh et al. 2007), only one study has compared the biodiversity of organisms in organic vs conventionally grown crops in Ireland. O'Sullivan and Gormally (2002) compared carabid beetle communities in organic and conventional potato crops and found a greater abundance (78\% higher) and diversity of beetles in the organic plots.

\section{CONCLUSIONS}

In the short-to-medium term $(0-20$ years $)$ agriculture in Ireland will face a number of challenges that will have an unknown impact on farmland biodiversity. These challenges include the reform of the CAP; the introduction of the Nitrate, Phosphate and Pesticide Directives; predicted climate change; a possible switch from food- to energy-crop planting; the potential abandonment of land in some regions of the country; and the possible introduction of genetically modified crop cultivation. In order to measure the impact of these new challenges on Irish biodiversity, baseline data of current levels of biodiversity under existing crop cultivation are necessary.

Publications on many crucial biodiversity aspects of conventional crop cultivation in Ireland are either scarce or non-existent, and many important taxa have never been studied at all. We have been unable to find peer-reviewed studies on the impact of crop cultivation on soil microorganisms (i.e. bacteria, fungi and protozoa), land mammals and many important insects, such as ladybirds and butterflies, nor any studies on the impacts from the use of integrated pest management as an alternative to conventional pesticide usage. No Irish-based studies have assessed the impact of growing oilseed rape on farmland biodiversity (e.g. on granivorous birds), in a time when acreage planted under rape is expected to increase in the coming years with the removal of sugar beet as the traditional break crop in cereal rotations and the increased interest in rapeseed oil for bio-diesel production.
In agreement with the international literature, there is evidence from our review of the available national literature that conventional methods of crop cultivation have had an adverse impact on the levels of biodiversity on Irish farms, with $\mathbf{1 5}$ of the 21 studies to date showing negative trends for the species and groups studied. However, many of these studies found that when more environmentally friendly farming practices are used on arable farms, adverse impacts on biodiversity can be reduced. A few studies listed in Table 1 clearly show the potential benefits of intercropping, minimum tillage, timing of cultivation, set-aside and winter stubble as possible approaches for increasing the biodiversity of the selected indicator taxa examined. Therefore, it is clear that arable farming per se is not detrimental to biodiversity and that in many cases it is likely more biodiversity-friendly farming practices can be devised and applied.

While many studies demonstrate the ecological advantages of the organic farming approach, there are calls for IFOAM-guided organic farming to be subjected to more scientific scrutiny (Trewavas 2004). With just one peer-reviewed publication from Ireland describing the positive impact of organic over conventional farming on carabid beetle abundance and diversity, both farmers and consumers generally rely on anecdotal evidence and data from non-Irish studies; for example, up to 2005 there were at least 76 published UK studies comparing conventional and organic farming (Hole et al. 2005). The conclusion from the comprehensive review by Hole et al. (2005) was that longitudinal, system-level studies are needed to address knowledge gaps regarding the impacts of organic farming before any full appraisal of its potential role in biodiversity conservation in agroecosystems can be made. Clearly, there is a need to conduct further research on the ecological impacts of organic cropping in Ireland, so that positive claims suggested by the organic industry sector can be substantiated through a comparative assessment against other tillage systems under Irish farming conditions.

The main issues in assessing impacts of arable farming on biodiversity in Ireland are the paucity of baseline data targeting different arable cropping systems (e.g. winter vs spring-sown crops, conventional vs organic, etc.) and the absence of long-term monitoring programmes specifically designed to assess positive or negative effects. While a National Biological Records Centre (NBRC) has now been established by the Irish government, there is, as yet, no comprehensive land-use monitoring system in place that allows changes in the landscape over decades to be investigated. Habitat inventories are largely confined to areas of special conservation concern, such as Natural Heritage Areas or Special Areas of Conservation (Fitzpatrick 
and Murray 2006). Although the establishment of the NBRC has been a considerable advance, the service it provides should not be considered an appropriate substitute for targeted research on different arable farming practices. A long-term research program, similar to the grassland 'AgBiota' project (Purvis et al. 2005), needs to be undertaken on arable farms as a matter of urgency. One of the aims of the Ag-Biota grassland-based project was to better identify and alleviate the main farming 'pressures' that may lead to significant biodiversity loss within the Irish countryside. In hindsight, there is little doubt that biodiversity on Irish farms should have been continuously monitored over the last few decades and that this could have been achieved with a fraction of the expenditure spent on the REPS scheme. Therefore, recent funding initiatives such as the EPA's Science and Technology, Research and Innovation for the Environment Programme (up to $€ 100$ million between 2007 and 2013 , $€ 5.2$ million of which will go towards biodiversity research themes) must be welcomed as they provide a mechanism to begin addressing the current knowledge deficit. The onus is now on the Irish research community to capitalise on this opportunity and generate the necessary data sets so that as the Irish tillage industry develops in response to global pressures (e.g. increased energy demands), the concurrent impact on Irish biodiversity is neutralised.

\section{ACKNOWLEDGEMENTS}

This work was funded under the EPA ERTDI Research Programme (Grant 2006-B-MS-46).

\section{REFERENCES}

Bardgett, R.D., Frankland, J.C. and Whittaker, J.B. 1993 The effects of agricultural management on the soil biota of some upland grasslands. Agriculture, Ecosystems and Environment 45, 25-45.

Bracken, F. 2004 The diversity of birds and butterflies in Irish lowland landscapes with special reference to the effects of set-aside management on birds in the breeding season. Unpublished $\mathrm{PhD}$ thesis, University College Dublin.

Bracken, F. and Bolger, T. 2006 Effects of set-aside management on birds breeding in lowland Ireland. Agriculture, Ecosystems and Environment 117, 178-84.

Brennan, A.S. 2005 Factors determining the structure and biodiversity of soil faunal assemblages in Irish lowland landscapes. Unpublished $\mathrm{PhD}$ thesis, University College Dublin.

Brennan, A., Fortune, T. and Bolger, T. 2006 Collembola abundances and assemblage structures in conventionally tilled and conservation tillage arable systems. Pedobiologia 50, 135-45.
Buckingham, D.L., Evans, A.D., Morris, A.J., Orsnzan, C.J. and Yaxley, R. 1999 Use of set-aside land in winter by declining farmland bird species in the UK. Bird Study 46, 157-69.

Costello, M.J. 1993 Biogeography of alien amphipods occurring in Ireland, and interactions with native species. Crustaceana 65, 287-99.

Coulter, B.S., Murphy, W.E., Culleton, N., Quinlan, G. and Connolly, L. 2005 A survey of fertilizer use from 2001-2003 for grassland and arable crops. End of project report. Wexford. Teagasc.

Curry, J.P., Byrne, D. and Schmidt, O. 2002 Intensive cultivation can drastically reduce earthworm populations in arable land. European Journal of Soil Biology 38, 127-30.

Curtis, T.G.F., McGough, H.N. and Wymer, E.D. 1988 The discovery and ecology of rare and threatened arable weeds, previously considered extinct in Ireland, on the Aran Islands, Co. Galway. Irish Naturalists' Journal 22, 505-12.

Davis, B.R. 2004 Field studies to evaluate less intensive management practices in winter wheat production. Unpublished MSc Thesis. University College Dublin.

Department of Agriculture and Food 2006a Compendium of Irish agricultural statistics 2006. Dublin. The Stationary Office.

Department of Agriculture and Food 2006b Pesticide usage survey: grassland and fodder crops 2003. Report number 1. Dublin. The Stationary Office.

Department of Agriculture and Food 2007 Pesticide usage survey: arable crops 2004. Report number 2. Dublin. The Stationary Office.

Diamond, J. 2005 Collapse: how societies choose to fail or survive. London. Penguin Books Ltd.

Donald, P.F., Green, R.E. and Heath, M.F. 2001 Agricultural intensification and the collapse of Europe's farmland bird populations. Proceedings of the Royal Society of London B 268, 25-9.

Erwin, D.H. 1996 The geologic history of diversity. In R.C. Szaro and D.W. Johnston (eds), Biodiversity in managed landscapes: theory and practice, 3-14. Oxford. Oxford University Press.

European Environment Agency 2005 Agriculture and environment in EU-15 the IRENA indicator report no. 6. Copenhagen. European Environment Agency.

Fadl, A.M. 1996 Studies on the effect of soil cultivation on the ecology of carabid beetles (Coleoptera: Carabidae) in arable land. Unpublished $\mathrm{PhD}$ thesis, University College Dublin.

Fadl, A., Purvis, G. and Towey, K. 1996 The effect of time of soil cultivation on the incidence of Pterostichus melanarius (Illig.) (Coleoptera: Carabidae) in arable land in Ireland. Annales Zoologici Fennici 33, 207-14.

Feehan, J. 2003 Farming in Ireland: history, heritage and environment. Dublin. Faculty of Agriculture, University College Dublin.

Feehan, J, Gillmor, D.A. and Culleton, N. 2005 Effects of an agri-environment scheme on farmland biodiversity in Ireland. Agriculture, Ecosystems and Environment 107, 275-86.

Fennessy, G.J. and Kelly, T.C. 2006 Breeding densities of Robin Erithacus rubecula in different 
habitats: the importance of hedgerow structure. Bird Study 53, 97-104.

Fitzpatrick, U. and Murray, T.E. 2006 Bee surveys on 44 protected sites in Ireland 2004-2005. Report to National Parks and Wildlife Service (Ireland) and Environment and Heritage Service (Northem Ireland). Belfast, National Parks and Wildlife Service; Dublin, Environment and Heritage Service.

Goklany, I.M. 1998 Saving habitat and conserving biodiversity on a crowded planet. Bioscience 48, 94153.

Golden,V. 2005 Factors determining the structure and biodiversity of carabid beetle assemblages in Irish lowland landscapes. Unpublished $\mathrm{PhD}$ thesis, University College Dublin.

Good, J.A. and Giller, P.S. 1988 A contribution to a check list of Staphylinidae (Coleoptera) of potential importance in the integrated protection of cereal and grass crops. In R. Cavalloro and K.D. Sunderland (eds), Integrated crop protection in cereals, 81-98. Rotterdam. A.A. Balkema.

Good, J.A. and Giller, P.S. 1991 The effect of cereal and grass management on staphylinid (coleoptera) assemblages in south-west Ireland. Joumal of Applied Ecology 28, 810-36.

Green, R.E. and Stowe, T.J. 1993 The decline of the comcrake Crex crex in Britain and Ireland in relation to habitat change. Joumal of Applied Ecology 30, 68995.

Hassan, R., Scholes, R. and Ash, N. 2005 Ecosystems and human well-being: current state and trends. Volume 1. Washington. Island Press.

Hole, D.G., Perkins, A.J., Wilson, J.D., Alexander I.H., Grice, P.V. and Evans, A.D. 2005 Does organic farming benefit biodiversity? Biological Conservation 122, 113-30.

Holzschuh, A., Steffan-Dewenter, I., Kleijn, D. and Tscharntke, T. 2007 Diversity of flowervisiting bees in cereal fields: effects of farming systems, landscape composition and regional context. Joumal of Applied Ecology 44, 41-9.

Hutton, S.A. and Giller, P.S. 2003 The effects of the intensification of agriculture on northern temperate dung beetle communities. Joumal of Applied Ecology 40, 994-1007.

IFOAM 2006 The IFOAM norms for organic production and processing. Germany. IFOAM.

Kelly, M.T. and Curry, J.P. 1985 Studies of the arthropod fauna of a winter wheat crop and its response to the pesticide methiocarb. Pedobiologia 28, 413-21.

Lack, P. 1992 Birds of lowland farms. London. Her Majesty's Stationery Office.

Lee, K.E. 1985 Earthworms: their ecology and relationships with soils and land use. Sydney. Academic Press.

Luff, M.L. 1987 Biology of polyphagous ground beetles in agriculture. Agricultural Zoology Reviews 2, 237-78.

Mäder. P., Fließbach, A., Dubois, D., Gunst, L., Fried, P. and Niggli U. 2002 Soil fertility and biodiversity in organic farming. Science 296, 1694-7.

McLaughlin, A. and Mineau, P. 1995 The impact of agricultural practices on biodiversity. Agriculture, Ecosystems and Environnent 55, 201-12.
McMahon, B.J. 2005 Avian biodiversity in farmland. Unpublished $\mathrm{PhD}$ thesis, University College Dublin.

McMahon, B.J., Whelan, J., Bracken, F. and Kavanagh, B. 2003 The impact of farming on overwintering bird populations. Teamann: Irish Joumal of Agri-environmental Research 3, 67-76.

Meade, C.V. and Mullins, E.D. 2005 GM crop cultivation in Ireland: ecological and economic considerations. Biology and Environment: Proceedings of the Royal Irish Academy 105B, 33-52.

Mitchell, F. and Ryan, M. 1997 Reading the Irish landscape. Dublin. Town House and Country House.

Murphy, W.E. 1982 Response to nitrogen in terms of grass production. In An Foras Taluntais grass production seminar, 69-74. Wexford. Johnstown Castle.

Newton, S., Donaghy, A., Allen, D. and Gibbons, D. 1999 Birds of conservation concern in Ireland. Irish Birds 6, 333-42.

O'Brien, M., O’Kiely, P., Forristal, P.D. and Fuller, H.T. 2008 Fungal contamination of big-bale grass silage on Irish farms: predominant mould and yeast species and features of bales and silage. Grass and Forage Science 63, 121-37.

O'Connor, R.J. and Shrubb, M. 1986 Farming and birds. Cambridge. Cambridge University Press.

OECD 2004 Compendium of agricultural statistics 2004. Paris. Environment Directorate, OECD.

O'Sullivan, C.M. and Gormally, M.J. 2002 A comparison of ground beetle (Carabidae: Coleoptera) communities in an organic and conventional potato crop. Biological Agriculture and Horticulture 20, 99110.

Pereira, H.M. and Cooper, H.D. 2006 Towards the global monitoring of biodiversity change. Trends in Ecology and Evolution 21, 123-9.

Pithon, J.A., Moles, R. and O'Halloran, J. 2005 The influence of coniferous afforestation on lowland farmland bird communities in Ireland: different seasons and landscape contexts. Landscape and Urban Planning 71, 91-103.

Purvis, G. and Bannon, J.W. 1992 Non-target effects of repeated methiocarb slug pellet application on carabid beetle (Coleoptera: Carabidae) activity in winter-sown cereals. Annals of Applied Biology 121, 401-22.

Purvis, G. and Curry, J.P. 1980 Successional changes in the arthropod fauna of a new ley pasture established on previously cultivated arable land. Journal of Applied Ecology 17, 309-21.

Purvis, G. and Curry, J.P. 1984 The influence of weeds and fammard manure on the activity of carabidae and other ground-dwelling arthropods in a sugar beet crop. Joumal of Applied Ecology 21, 27183.

Purvis, G. and Fadl, A. 2002 The influence of cropping rotations and soil cultivation practice on the population ecology of carabids (Coleoptera: Carabidae) in arable land. Pedobiologia 46, 452-74.

Purvis, G., Fadl, A. and Bolger, T. 2001 A multivariate analysis of cropping effects on Irish ground beetle assemblages (Coleoptera: Carabidae) 
in mixed arable and grass farmland. Annals of Applied Biology 139, 351-60.

Purvis, G., Bolger, T., Breen, J., Connolly, J., Curry, J., Finn, J., Kelly-Quinn, M., Kennedy, T., Schmidt, O., Schulte, R. and Whelan, J. 2005 The significance of biodiversity in agriculture: relevance, aims and progress of the Ag-Biota project. Tearmann: Irish Journal of Agri-environmental Research 4, 29-50.

Reynolds, S.C.P. 2002 A catalogue of alien plants in Ireland. Glasnevin, Dublin. National Botanic Gardens.

Robinson, R.A. and Sutherland, W.J. 2002 Post-war changes in arable farming and biodiversity in Great Britain. Joumal of Applied Ecology 39, 157-76.

Russ, J.M. and Montgomery, W.I. 2002 Habitat associations of bats in Northern Ireland: implications for conservation. Biological Conservation 108, 49-58.

Santorum, V. and Breen, J. 2005 Bumblebee diversity on Irish farmuland. Tearmann: Irish Journal of Agrienvironmental Research 4, 79--90.

Schmidt, O. and Curry J.P. 2001 Population dynamics of earthworms (Lumbricidae) and their role in nitrogen tumover in wheat and wheat-clover cropping systems. Pedobiologia 45, 174-87.

Schmidt, O., Curry, J.P., Hackett, R.A., Purvis, G. and Clements, R.O. 2001 Earthworm communities in conventional wheat monocropping and lowinput wheat-clover intercropping system. Annals of Applied Biology 138, 377-88.

Shortle, G., Burke, J. and Reidy, J. 2007 Potential of organic tillage in Ireland. In Proceedings of the National Tillage Conference, Carlow, 31 January 2007 , 78-92. Carlow. Teagasc.

Smil, V. 2002 Nitrogen and food production: proteins for human diets. Ambio 31, 126-31.
Sotherton, N.W. 1998 Land use changes and the decline of farmland wildlife: an appraisal of the set-aside approach. Biological Conservation 83, 25968.

Stokes, K., O'Neill, K. and McDonald, R. 2004 Invasive species in Ireland. Unpublished report to Environment and Heritage Service and National Parks and Wildlife Service. Belfast. Quercus, Queen's University Belfast.

Taylor, A.J. and O'Halloran, J. 2002 The decline of the corn bunting, Miliaria calandra, in the Republic of Ireland. Biology and Environment: Proceedings of the Royal Irish Academy 102B, 165-75.

Teagasc 2007 Rural Environment Protection Scheme, available at http://www.environment.teagasc.ie/ reps/reps.asp (1 August 2008).

The Heritage Council 1999 Impact of agriculture schemes and payntents on aspects of Ireland's heritage. Kilkenny. The Heritage Council.

Thiele, H.U. 1977 Carabid beetles in their enviromments. Berlin. Springer-Verlag.

Thompson, I.D. 2006 Monitoring of biodiversity indicators in boreal forests: a need for improved focus. Environmental Monitoring and Assessment 121, 263-73.

Trewavas, A. 2004 A critical assessment of organic farming and food assertions with particular respect to the UK and the potential environmental benefits of no-till agriculture. Crop Protection 23, 757-81.

Webb, R. 1988 The status of hedgerow field margins in Ireland. In J.R. Park (ed), Environment management in agriculture: European perspective. Proceedings of a workshop held from 14 to 17 July 1987 at Bristol, United Kingdom, under the aegis of the CEC land and water use and management committee, 125-31. London. Belhaven Press. 